\title{
Diel variations in photosynthetic activity of summer phytoplankton in Lindåspollene, western Norway
}

\author{
S. R. Erga ${ }^{1}$, H. R. Skjoldal ${ }^{2}$ \\ ${ }^{1}$ Norwegian Institute for Water Research, Breiviken 5, N-5035 Bergen-Sandviken, Norway \\ ${ }^{2}$ Institute of Marine Research, PO Box 1870, Nordnes, N-5024 Bergen, Norway
}

\begin{abstract}
Diel patterns in photosynthesis of natural phytoplankton were studied during a $5 \mathrm{~d}$ period during midsummer in Lindåspollene, a land-locked fjord of western Norway. Samples were taken from depths of $0.5,5,10$ and $21 \mathrm{~m}$ at 3 to $4 \mathrm{~h}$ intervals. The natural light:dark cycle was 19:5 h. The coccolithophorid Emiliania huxleyi and ultraplankton $(<5 \mu \mathrm{m})$ flagellates were predominant in the upper $10 \mathrm{~m}$, while diatoms and silicoflagellates were predominant at $21 \mathrm{~m}$. No clear diel pattern was seen in the variations of chlorophyll $a$ and cell numbers. The photosynthesis vs light relationship (P-I) was studied at 0.5 and $10 \mathrm{~m}$, and the parameters $\mathrm{P}_{\text {max }}^{\mathrm{B}}, \alpha^{\mathrm{B}}$ and $\mathrm{I}_{\mathrm{K}}$ showed pronounced diel rhythms. Maximum and minimum values of $\alpha^{B}$ and $P^{B}{ }_{\text {max }}$ differed by a factor of 3 to 4 and occurred in the morning and evening periods, respectively. These parameters were linearly correlated at both 0.5 and $10 \mathrm{~m}$, indicating a phased diel periodicity. $\mathrm{I}_{\mathrm{K}}$ showed a clear diel variation at $0.5 \mathrm{~m}$ with minimum values at night, whereas no persistent diel rhythm could be seen at $10 \mathrm{~m} . \mathrm{P}^{\mathrm{B}}{ }_{\max }$ and $\mathrm{I}_{\mathrm{K}}$ were correlated at $0.5 \mathrm{~m}$ but not at $10 \mathrm{~m}$, while $\mathrm{I}_{\mathrm{K}}$ and $\alpha^{\mathrm{B}}$ were weakly correlated at both 0.5 and $10 \mathrm{~m}$. In vivo fluorescence per unit chlorophyll a showed a diel variation pattern that was the opposite to that of $\mathrm{P}^{\mathrm{B}}{ }_{\max }$ and $\alpha^{\mathrm{B}}$ Our results indicate that an endogenous rhythm is regulating the diel oscillations in photosynthesis. This endogenous mechanism is possibly entrained by environmental signals such as cycles in nutrient availability and light conditions.
\end{abstract}

\section{INTRODUCTION}

During the last 2 decades a research program has been in progress on the plankton community of Lindåspollene, a land-locked fjord of western Norway (Lännergren 1976, Lännergren \& Skjoldal 1976, Skjoldal \& Lännergren 1978, Aksnes \& Magnesen 1983, 1988, Lie et al. 1983, Skjoldal et al. 1983, Wassmann 1983, Aksnes et al. 1985, Skjoldal \& Wassmann 1986). One aim of the investigations has been to establish a deterministic simulation model of the phytoplankton and zooplankton growth dynamics and their trophic interactions. Fundamental in this context is the assessment of daily primary production. Great errors may occur when estimating production if the influence of diel variations in photosynthesis is neglected (MacCaull \& Platt 1977).

The occurrence of periodic diel variations in photosynthetic properties of natural marine phytoplankton was first reported by Doty \& Oguri (1957) and has since then been frequently observed (e.g. Lorenzen 1963, McAllister 1963, Malone 1971, Sournia 1974, Taguchi
1976, MacCaull \& Platt 1977, Pearl \& Mackenzie 1977, Gargas et al. 1979, Prézelin \& Ley 1980, Harding et al. 1982a, b, Setser et al. 1982, Fuhrman et al. 1985, Putt \& Prézelin 1985, 1988, Prézelin et al. 1986, 1987, Glover \& Smith 1988, Legendre et al. 1988, Putt et al. 1988, Rivkin \& Putt 1988). Diel patterns in photosynthetic capacity occur among a wide range of phytoplankton species (Eppley \& Coatsworth 1966, Prézelin \& Sweeney 1977, Hitchcock 1980, Marra 1980, Owens et al. 1980, Prézelin \& Matlick 1980, Harding et al. 1981a, b, Brand 1982, Cosper 1982, Marra \& Heinemann 1982, Harding et al. 1983, Samuelsson et al. 1983, Harding \& Heinbokel 1984, Vårum et al. 1986, Putt \& Prézelin 1988). It is usually believed that the diel oscillations in photosynthetic properties are due to an endogenous mechanism (circadian clock) which is entrained by changes in environmental factors (Enright 1970, Stross et al. 1973).

When considering variations in primary production, it is difficult to separate the effect of diel rhythms in the photosynthetic parameters $\alpha$ and $P_{\max }$ (Platt \& Jassby 
1976), and photoadaptive responses often encountered among algal cells exposed to different light intensities (Harding et al. 1983). Such adaptations depend upon the degree of vertical mixing and turbidity. Under conditions of low vertical mixing, 'light-adapted' and 'shade-adapted' cells may be found near the surface and at the bottom of the euphotic zone, respectively. The shade-adapted cells are characterized by either increased size of the photosynthetic unit (PSU) or increased number of PSUs (reviews: Falkowski 1980, Prézelin 1981), which is considered to improve their photosynthetic capacity. Marra (1978), on the other hand, found no depressed photosynthesis in a windmixed water column compared with that of a wellstratified water column. The same result emerged from an investigation by Quéguiner \& Legendre (1986), who found that phytoplankton could adapt their photosynthetic characteristics to a rapidly fluctuating light regime.

Here we report on diel rhythms of photosynthesis of natural phytoplankton at different depths $(0.5,5$ and $10 \mathrm{~m}$ ) studied during 5 consecutive 24 h periods during midsummer in Lindasspollene. This land-locked fjord has restricted tidal water exchange and a stable water column with a relatively marked density gradient extending almost from the surface to about $20 \mathrm{~m}$ (e.g. Skjoldal \& Wassmann 1986). Apart from the upper few meters, vertical mixing is therefore very restricted. By comparing 3 depths, our approach was to describe diel rhythms for phytoplankton experiencing different light intensities in a stable physical environment, which would allow adaptation to occur. More information on the vertical structure of the environment and the phytoplankton community will be given in another paper (Skjoldal \& Erga unpubl.).

\section{MATERIALS AND METHODS}

All sampling and experiments were conducted from an anchored wooden raft (water depth $40 \mathrm{~m}$ ), situated at the northern part of Spjeldnesosen, the mid-basin of Lindaspollene. For a description of the sampling area and information on the topography see Dahl et al. (1973).

Samples were obtained through 3 nontoxic polyethylene tubes ending at $0.5,5$ and $10 \mathrm{~m}$, by using a vacuum pump connected to 51 reservoir flasks. Additional samples were taken from $21 \mathrm{~m}$ by a $5 \mathrm{l}$ Ruttner water bottle. Special care was taken to protect samples against strong light. On 33 occasions, from 15:30 h local time on 7 June to $16: 30 \mathrm{~h}$ local time on 12 June, samples were collected for analyses of salinity, temperature, $\mathrm{pH},{ }^{14} \mathrm{C}$-assimilation, in vivo fluorescence, chlorophyll $a_{1}$ and phytoplankton abundance and composition. Samples for analysis of particulate organic carbon, nitrogen, and phosphorus were also taken, but these results are not reported here. The samples were taken at $3 \mathrm{~h}$ intervals during the first day and at $4 \mathrm{~h}$ intervals during the subsequent $4 \mathrm{~d}$. In order to reduce the effect of grazing during incubation, and the effect of zooplankton on phytoplankton biomass estimates, all samples were prescreened $(60 \mu \mathrm{m})$ upon transfer from the reservoir flasks to 51 plastic carboys. This could be done due to the predominance of small phytoplankton forms during summer. Samples of chlorophyll $a$ and ${ }^{14} \mathrm{C}$-assimilation were filtered onto Whatman GF/C filters and stored frozen prior to analysis.

Primary production was measured according to the ${ }^{14} \mathrm{C}$-method (Steemann Nielsen 1952). Incubations were conducted in a temperature-controlled incubator equipped with a fluorescent light bank (Philips TL 20 W/33). The incubation bottles ( $25 \mathrm{ml}$ borosilicate-glass) were mounted on a rotating wheel and exposed to 7 different light intensities ranging from 16 to $900 \mu \mathrm{E} \mathrm{m}^{-2}$ $\mathrm{s}^{-1}(400$ to $700 \mathrm{~nm})$. The light gradient was achieved by neutral density filters, with the maximum value being obtained by a reflector mounted behind the bottle. The incubation time was $2 \mathrm{~h}$ which is reported to give rates approaching gross photosynthesis (Dring \& Jewson 1982). Calculations of ${ }^{14} \mathrm{C}$-uptake rates were as described by Erga \& Heimdal (1984) and no corrections were made to compensate for excretion of photosynthesized products during incubation (see Erga 1989b). Data on in situ primary production measurements are taken from Skjoldal \& Erga (unpubl.).

At each sampling, the $P$ vs I relationship was determined for samples from 0.5 and $10 \mathrm{~m}$. The photosynthetic parameters $\alpha^{B}$ (initial slope of the light saturation curve), $\mathrm{I}_{\mathrm{K}}=\mathrm{P}_{\max } / \alpha$ (irradiance at which the prolongation of the initial and horizontal parts of the photosynthesis curve intersect) and $\mathrm{P}_{\text {max }}^{\mathrm{B}}$ (specific production rate at optimal light intensity) were derived from the equation of optimal curve adaptation as presented by Platt et al. (1980). Samples from 5 and $21 \mathrm{~m}$ were incubated at

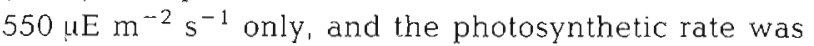
assumed to represent $\mathrm{P}^{\mathrm{B}}$ max. For the shade-adapted cells at $21 \mathrm{~m}$, however, this light intensity was probably higher than optimum, and $\mathrm{P}_{\text {max }}^{B}$ therefore, may be underestimated due to photoinhibition.

In vivo fluorescence of the water samples was determined using a Turner Designs fluorometer Chlorophyll a was analyzed fluorometrically with methanol as solvent (Holm-Hansen \& Riemann 1978). Light measurements and light conversion factors were as given by Erga (1989a). Salinity was measured by an Autolab Salinometer. Phytoplankton abundance was determined according to Utermöhl (1931), using neutralized formalin as preservative. 


\section{RESULTS}

\section{Light and hydrography}

The weather was clear and sunny throughout the period of investigation. The maximum surface irradiance at noon was $1550 \mu \mathrm{E} \mathrm{m}^{-2} \mathrm{~s}^{-1}$ and the natural light:dark (L:D) cycle was 19:5 h (cf. Fig. 1). The turbidity of the water was nearly constant from 7 to 12 June (Fig. 1), and the $1 \%$ light depth was ca $20 \mathrm{~m}$.

Surface salinities changed markedly from 8 to 9 June (Fig. 2). This probably had nothing to do with freshwater runoff since there was no precipitation in June prior to our investigation. No consistency was found between the salinity variations of the upper $5 \mathrm{~m}$ of the water column and the semidiurnal tidal cycle (Fig. 2). The very low tidal amplitude in Lindasspollene indicates that tidal forces are of little importance in this context. Most likely, the observed changes in salinity were associated with wind-driven currents. Relatively strong winds from the south on 7 June were followed by northerly winds on 8 June. This probably resulted in an accumulation of less saline surface water at the site of the raft (northern end of Lindasspollene) on 7 June, while on 8 June more saline water was vertically advected to compensate for a south-flowing surface layer. These exchange processes were, however, restricted to the upper $10 \mathrm{~m}$ of the water column as revealed by the unchanged salinity at $10 \mathrm{~m}$ (Fig. 2).

The salinity of the surface layer was about 29.5 and the temperature was around $15^{\circ} \mathrm{C}$. Salinity and temperature changed with depth to about 31 and $5{ }^{\circ} \mathrm{C}$, respectively, at $20 \mathrm{~m}$. Inorganic nutrients were uniformly low down to $15 \mathrm{~m}$ (Skjoldal \& Erga unpubl.).

\section{Diel variations in photosynthetic activity}

Rates of carbon assimilation showed a clear diel pattern, with maximum values in the morning period
Fig. 1. Light attenuation for the upper $25 \mathrm{~m}$ of the water column in Lindåspollene during the period 7 to 12 June 1982. Surface irradiance throughout the day are given in the inset
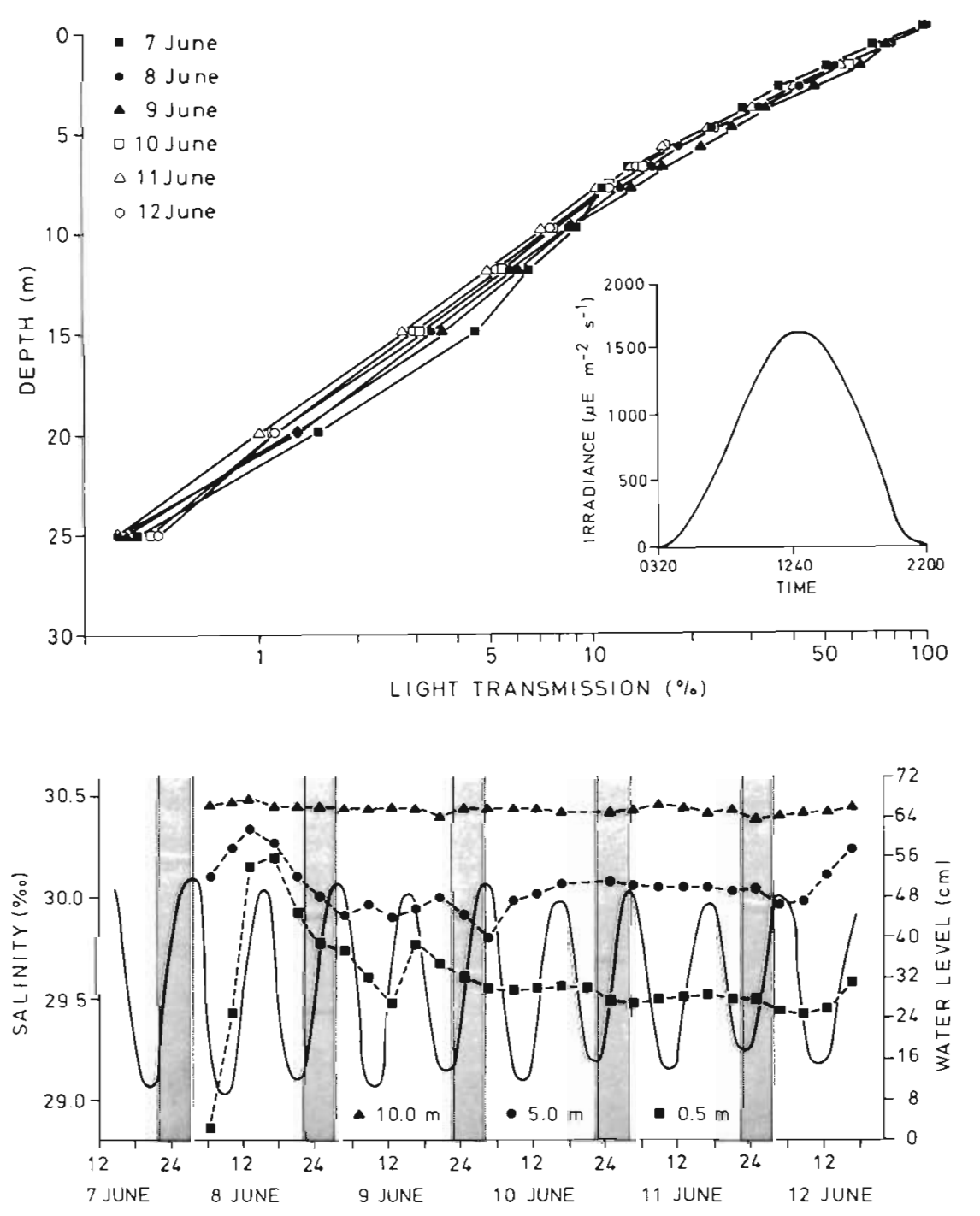

Fig. 2. Salinities at $0.5,5$ and $10 \mathrm{~m}$ (broken line) and tidal water level variations (continuous line) during the period 7 to 12 June 1982 in Lindasspollene. Shaded columns show periods of darkness 
and minimum values in late evening (Fig. 3). The ratio of in vivo fluorescence to chlorophyll a (IVF/chl a) appeared to vary inversely with carbon assimilation, showing low values in the morning and high values in the evening (Fig. 4). This pattern, however, was less consistent with respect to a diel rhythm than that of the carbon assimilation. There was no clear evidence of a diel pattern in the variations of chlorophyll a (Fig. 4). Low concentrations at $0.5 \mathrm{~m}$ and high concentrations at $10 \mathrm{~m}$ during the day seemed, however, to be recurrent events.

The maximal carbon assimilation rate $\left(\mathrm{P}_{\max }\right)$ showed a general increase with depth (Table 1). The high $\mathrm{P}_{\max }$ values at $21 \mathrm{~m}$ were apparently not due to higher biomass, as concentrations of particulate organic carbon, nitrogen, and phosphorus were lower there than in the upper layer (Skjoldal \& Erga unpubl.). They reflected, on the other hand, increased cellular levels of chlorophyll $a$ in the deeper layer (Fig. 5).

The $\mathrm{P}$ vs I curve parameters, $\mathrm{P}_{\text {max }}^{\mathrm{B}} \alpha^{\mathrm{B}}$ and $\mathrm{I}_{\mathrm{K}}$ (Platt et al. 1980), revealed pronounced diel patterns (Figs. 6 and 7 ). Due to the relatively small temporal variations in chlorophyll a (Fig. 4), the pattern of changes in $\mathrm{P}^{\mathrm{B}}$ max (normalized to chlorophyll a) was not much different from that of $P_{\max }$ (Fig. 3). Both the lowest and highest $\mathrm{P}^{\mathrm{B}}{ }_{\max }$ values were found at $0.5 \mathrm{~m}$ (Table 1). The amplitude of the diel oscillations in $\mathrm{P}^{\mathrm{B}}$ max seemed to decrease with increasing depth whereas the mean $\mathrm{P}_{\text {max }}^{\mathrm{B}}$ values changed little.

There was a diel covariation of $\alpha^{\mathrm{B}}$ and $\mathrm{P}^{\mathrm{B}}$ max (Fig. 6). Maximum and minimum values occurred in the morning and evening periods, respectively. The range of $\alpha^{B}$ values changed little from 0.5 to $10 \mathrm{~m}$ depth (Table 1).

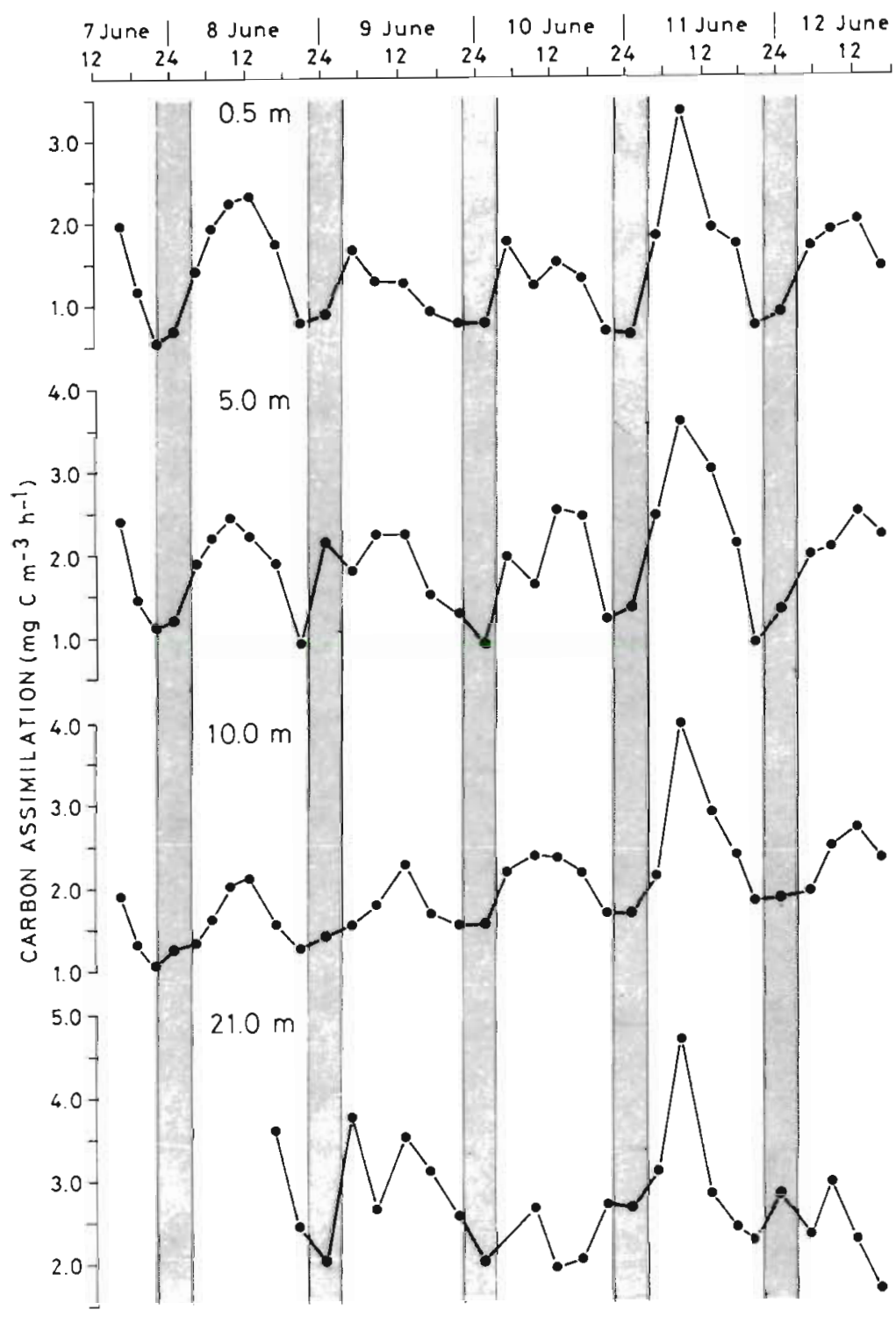

Fig. 3. Diel changes in carbon assimilation at $0.5,5.10$ and $21 \mathrm{~m}$ from 7 to 12 June 1982 in Lindåspollene. Shaded columns show periods of darkness 
Fig. 4. Diel variations in chlorophyll a concentrations and in vivo fluorescence/ chlorophyll a ratios at $0.5,5$ and $10 \mathrm{~m}$ during the period 7 to 12 June 1982 in Lindåspollene. Shaded columns show periods of darkness

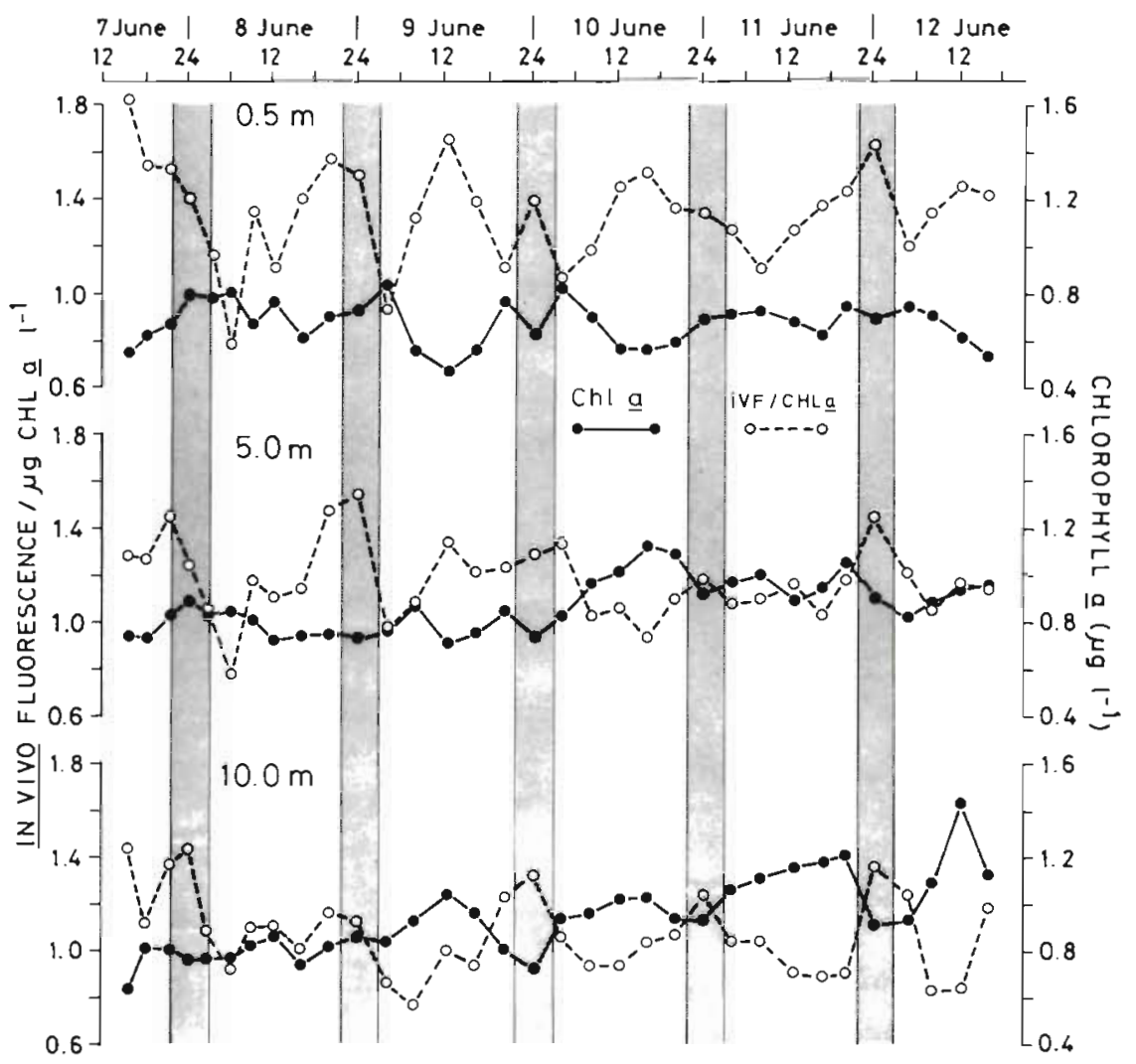

Table 1. Maximum (max), minimum (min) and mean values $(\overline{\mathrm{x}})$ of chlorophyll a $\left(\mathrm{Chl}\right.$ a), maximal carbon assimilation rate $\left(\mathrm{P}_{\max }\right.$, mg $\mathrm{C} \mathrm{m}^{-3} \mathrm{~h}^{-1}$ ), photosynthetic capacity $\left(\mathrm{P}_{\max }^{\mathrm{B}}, \mathrm{mg} \mathrm{C} \mathrm{mg} \mathrm{chl} \mathrm{a}^{-1} \mathrm{~h}^{-1}\right)$, light utilization efficiency ( $\left.\alpha^{\mathrm{B}}, \mathrm{mg} \mathrm{C} \mathrm{mg} \mathrm{chl} a^{-1} \mathrm{~h}^{-1} \mu \mathrm{E}^{-1} \mathrm{~m}^{2} \mathrm{~s}\right)$ and light-saturation intensity $\left(I_{K}, \mu \mathrm{E} \mathrm{m}^{-2} \mathrm{~s}^{-1}\right)$ at $0.5,5$ and $10 \mathrm{~m}$ depth for the period 7 to $12 \mathrm{June} 1982$ in Lindaspollene. At $5 \mathrm{~m}, \alpha^{B}$ and $\mathrm{I}_{\mathrm{K}}$ were not measured. $\mathrm{P}_{\max }$ was also measured at $21 \mathrm{~m}$. $\mathrm{n}$ : number of samples, $\mathrm{SD}$ : standard deviation

\begin{tabular}{|c|c|c|c|c|c|c|c|c|c|c|c|c|c|c|c|c|}
\hline \multirow[t]{2}{*}{ Parameters } & \multicolumn{4}{|c|}{$0.5 \mathrm{~m}$} & \multicolumn{4}{|c|}{$5 \mathrm{~m}$} & \multicolumn{4}{|c|}{$10 \mathrm{~m}$} & \multicolumn{4}{|c|}{$21 \mathrm{~m}^{\mathrm{a}}$} \\
\hline & $\overline{\mathrm{x}}$ & $\underset{\max }{\min }$ & $\mathrm{SD}$ & $\mathrm{n}$ & $\overline{\mathrm{x}}$ & $\begin{array}{c}\max \\
\min \end{array}$ & $\mathrm{SD}$ & $\mathrm{n}$ & $\bar{x}$ & $\begin{array}{c}\max \\
\min \end{array}$ & $\mathrm{SD}$ & $\mathrm{n}$ & $\overline{\mathrm{x}}$ & $\begin{array}{c}\max \\
\min \end{array}$ & $\mathrm{SD}$ & $\mathrm{n}$ \\
\hline Chl a & 0.67 & $\begin{array}{l}0.84 \\
0.47\end{array}$ & 0.09 & 33 & 0.87 & $\begin{array}{l}1.12 \\
0.71\end{array}$ & 0.11 & 33 & 0.94 & $\begin{array}{l}1.83 \\
0.64\end{array}$ & 0.17 & 33 & - & $\begin{array}{l}- \\
-\end{array}$ & - & - \\
\hline$P_{\max }$ & 1.45 & $\begin{array}{l}3.37 \\
0.54\end{array}$ & 0.62 & 33 & 1.91 & $\begin{array}{l}3.51 \\
0.91\end{array}$ & 0.63 & 33 & 1.97 & $\begin{array}{l}3.97 \\
1.10\end{array}$ & 0.57 & 33 & 2.70 & $\begin{array}{l}4.65 \\
1.66\end{array}$ & 0.68 & 24 \\
\hline $\mathrm{P}_{\max }^{\mathrm{B}}$ & 2.26 & $\begin{array}{l}4.62 \\
0.85\end{array}$ & 1.06 & 33 & 2.22 & $\begin{array}{l}3.58 \\
1.10\end{array}$ & 0.72 & 33 & 2.07 & $\begin{array}{l}3.58 \\
1.36\end{array}$ & 0.47 & 33 & - & $\begin{array}{l}- \\
-\end{array}$ & - & - \\
\hline$\alpha^{B} \times 10^{-3}$ & 10.1 & $\begin{array}{r}18.7 \\
6.3\end{array}$ & 2.9 & 33 & - & $\begin{array}{l}- \\
-\end{array}$ & - & - & 10.4 & $\begin{array}{r}20.8 \\
7.0\end{array}$ & 3.2 & 33 & - & - & - & - \\
\hline$I_{K}$ & 215 & $\begin{array}{r}311 \\
96\end{array}$ & 61.9 & 33 & - & $\begin{array}{l}- \\
-\end{array}$ & - & - & 202 & $\begin{array}{l}282 \\
149\end{array}$ & 27.5 & 33 & - & - & - & - \\
\hline
\end{tabular}

At $0.5 \mathrm{~m}, \mathrm{I}_{\mathrm{K}}$ showed a pronounced diel variation with values being high during the midday hours and decreasing to minimum in late evening or early night (Fig. 6). In contrast, no clear diel rhythm was found at $10 \mathrm{~m}$. Mean values of $I_{K}$ did not change significantly from 0.5 to $10 \mathrm{~m}$ depth (Table 1). $\alpha^{\mathrm{B}}$ and $\mathrm{P}^{\mathrm{B}}$ max were significantly correlated at both 0.5 and $10 \mathrm{~m}$ (Table 2 ). The relationship was apparently linear, but differed between the 2 depths (Fig. 8) (see 'Discussion' for further comments). $\mathrm{P}^{\mathrm{B}}$ max showed a significant positive correlation with $\mathrm{I}_{\mathrm{K}}$ at $0.5 \mathrm{~m}$, 


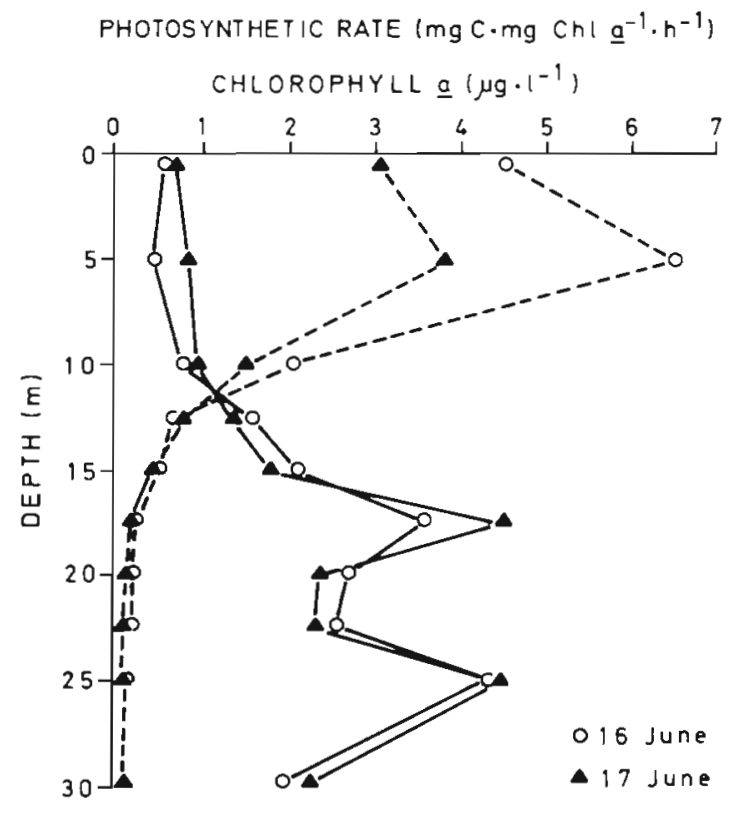

Fig. 5. Vertical profiles of chlorophyll a concentration (continuous line) and photosynthetic rate (broken line) on 16 and 17 June 1982 in Lindåspollene

but not at $10 \mathrm{~m}$ (Table 2) since no diel rhythm in $\mathrm{I}_{\mathrm{K}}$ was found at this depth. $\alpha^{B}$ and $I_{K}$ were not significantly correlated at any depth (Table 2).

There were no strong indications of photoinhibition at irradiances up to $900 \mu \mathrm{E} \mathrm{m}^{-2} \mathrm{~s}^{-1}$ (Fig. 7). The in situ primary production measurements (Fig.5) suggest, however, that photoinhibition probably occurred for surface phytoplankton at irradiances exceeding $1000 \mu \mathrm{E} \mathrm{m}^{-2} \mathrm{~s}^{-1}$ (Fig. 1). Harris (1980) concluded that this value represents a threshold value concerning photoinhibition for natural phytoplankton.

\section{Species composition and abundance}

Phytoplankton were enumerated for 4 major categories: coccolithophorids, diatoms, dinoflagellates, and unidentified ultraplankton $(<5 \mu \mathrm{m})$ flagellates. Coccolithophorids and ultraplankton flagellates dominated at 0.5 and $5 \mathrm{~m}$ depths in terms of both cell numbers (Fig. 9) and biomass. Diatoms at these depths appeared to be in poor physiological condition as judged from low content of protoplasm and frustules covered by bacteria. The high cell numbers of diatoms in the surface layer on 8 June coincided with the intrusion of more saline water (Fig. 2). The number of coccolithophorids decreased strongly from 5 to $10 \mathrm{~m}$, while for the other groups the differences were relatively small (Fig.9). At $21 \mathrm{~m}$ (about 1\% light depth) centric diatoms and silicoflagellates were the most important groups.
Emiliania huxleyi and Rhizosolenia delicatula were totally dominant among coccolithophorids and diatoms, respectively, in the upper $10 \mathrm{~m}$ of the water column. E. huxleyi seemed to grow under conditions of low nutrients, high irradiance and relatively high temperatures. This reflects a competitive advantage of this species under such circumstances (Berge 1962, Eppley et al. 1969, Erga \& Heimdal 1984). Okada \& Honjo (1973) concluded that coccolithophorids are particularly successful in oligotrophic environments. Further details on the vertical structure and species composition of the phytoplankton community will be given elsewhere (Skjoldal \& Erga unpubl.).

The standing stocks of the different groups of phytoplankton did not change significantly during the period of investigation (Fig. 9). In most cases diel variations in cell numbers were within the counting error (Fig.9). One exception was the peak in diatom abundance at the beginning of the investigation. The maximum at $0.5 \mathrm{~m}$ was followed 11 and $35 \mathrm{~h}$ later by peaks at 5 and $10 \mathrm{~m}$, respectively. This could have been due to sinking. The delay in the diatom peak from 5 to $10 \mathrm{~m}$ corresponds to an apparent sinking rate of $5 \mathrm{~m} \mathrm{~d}^{-1}$. which is in good agreement with the maximum values given by Lännergren (1979) for natural populations of marine phytoplankton.

\section{DISCUSSION}

\section{Environmental conditions}

Environments with stable conditions over relatively long periods (days to weeks) are useful in studying diel rhythms in the photosynthetic activity of natural phytoplankton. Polls (land-locked fjords) are unique in this context due to very restricted exchange processes with the fjords outside (Matthews \& Heimdal 1980). A stratified water column is typically found in Lindåspollene in June (Aure 1972, Skjoldal et al. 1983, Skjoldal \& Erga unpubl.). It is characterized by low nutrient content and moderately low phytoplankton biomass in the upper $10 \mathrm{~m}$ (Lännergren 1976, Skjoldal et al. 1983). As a rule, the main peak in zooplankton biomass ( $>60 \mu \mathrm{m}$, dominated by small copepods) is situated around $10 \mathrm{~m}$, and little vertical migration is found among the predominant species (Lie et al. 1983, Aksnes \& Magnesen 1988, Magnesen et al. 1989). It is therefore unlikely that the diel patterns in photosynthetic activity observed in the upper $10 \mathrm{~m}$ of the water column in Lindåspollene were due to grazing by zooplankton. This is also supported by the fact that no pronounced diel pattern in chlorophyll a concentrations was found (Fig. 4). Litaker et al. (1988), on the other hand, found that grazing by microzooplankton 
Fig. 6. Diel variations (A) in $\alpha^{\mathrm{B}}$ (broken line) and $\mathrm{P}_{\max }^{\mathrm{B}}\left(\mathrm{P}_{\mathrm{m}}^{\mathrm{B}}\right.$, continuous line $)$ at 0.5 and $10 \mathrm{~m}$, and $(B)$ in $I_{K}$ at 0.5 and $10 \mathrm{~m}$, during the period 7 to 12 June 1982 in Lindåspollene. Shaded columns show periods of darkness

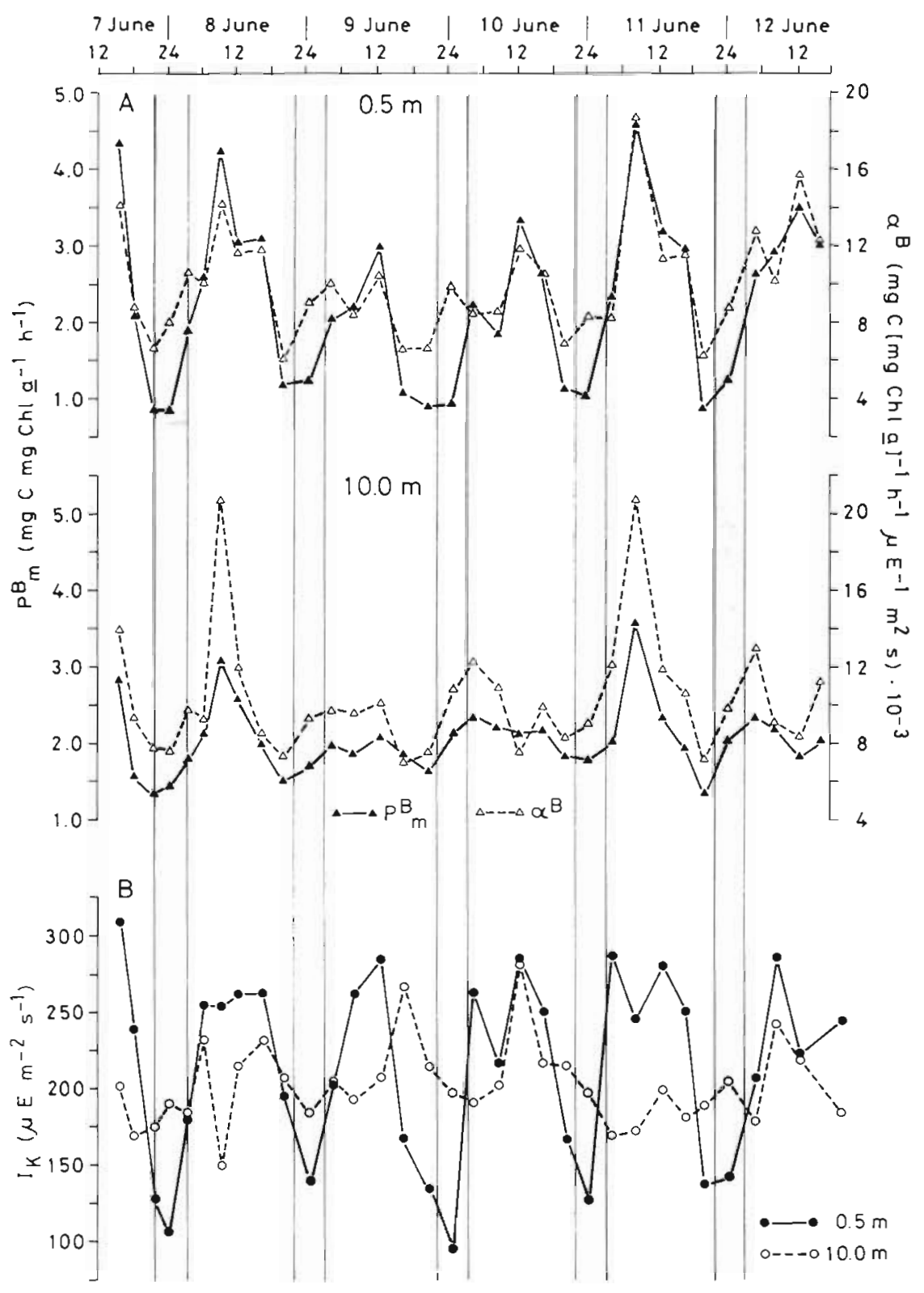

contributed substantially to diel changes in phytoplankton biomass (chlorophyll a) in Newport River Estuary, North Carolina (USA).

Another characteristic feature of the environmental conditions in Lindaspollene during the period of investigation was the very high surface irradiance, $1550 \mu \mathrm{E}$ $\mathrm{m}^{-2} \mathrm{~s}^{-1}$, around noon, and a natural L:D cycle of $19: 5 \mathrm{~h}$ (see 'Results'). The irradiance around noon decreased from between 300 and $350 \mu \mathrm{E} \mathrm{m}^{-2} \mathrm{~s}^{-1}$ at $5 \mathrm{~m}$ depth to between 100 and $140 \mu \mathrm{E} \mathrm{m}^{-2} \mathrm{~s}^{-1}$ at $10 \mathrm{~m}$. Paasche (1967) reported $140 \mu \mathrm{E} \mathrm{m} \mathrm{m}^{-2} \mathrm{~s}^{-1}$ to be the lower irradiance for optimal growth of Emiliania huxleyi, and this is identical to the maximum irradiance at $10 \mathrm{~m}$. Cell numbers of $E$. huxleyi decreased considerably below $5 \mathrm{~m}$ depth in Lindåspollene (Fig. 9). As judged from cell counts at $5 \mathrm{~m}$ depth, E. huxleyi was dividing both in the light and in the dark. This is supported by the results of Nelson \& Brand (1979), while Paasche (1967) found that another clone of the species divided only in the dark.

\section{Factors controlling the diel rhythm of photosynthesis}

A clear diel rhythm was found in the rate of photosynthesis, in terms of $\alpha^{\mathrm{B}}$ and $\mathrm{P}^{\mathrm{B}}{ }_{\max }$, of the summer phytoplankton in Lindåspollene. A pattern of increasing rates of $\alpha^{\mathrm{B}}$ and $\mathrm{P}_{\text {max }}^{\mathrm{B}}$ in the early morning with 


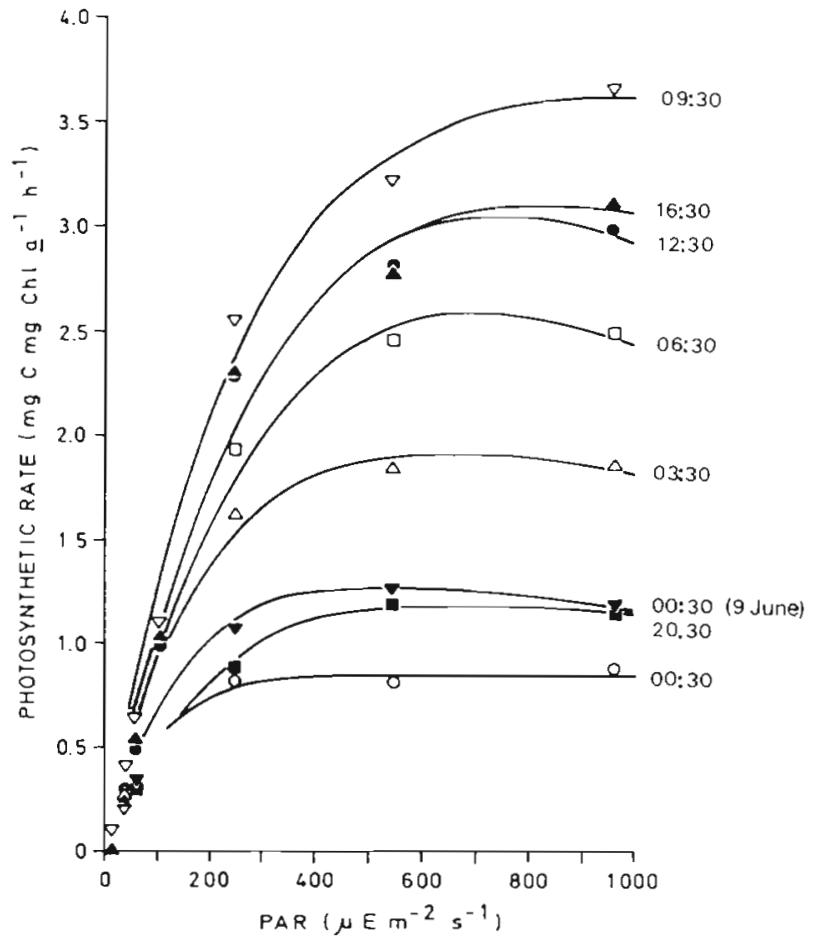

Fig. 7. Diel change in the photosynthesis vs irradiance relationship for phytoplankton taken from $0.5 \mathrm{~m}$ depth on 8 June 1982 in Lindåspollene

maximum values occurring before noon, and decreasing rates during the afternoon, was a persistent feature (Figs. 6 and 7). This is a common pattern that has been documented for several species of phytoplankton (Lorenzen 1963, McAllister 1963, Harding et al. 1981a,
Table 2. Linear regression analysis (Ricker 1973) of the relationships between photosynthetic capacity $\left(P_{\max }^{\mathrm{B}}\right)$, light utilization efficiency $\left(\alpha^{\mathrm{B}}\right)$, and light saturation intensity $\left(\mathrm{I}_{\mathrm{K}}\right)$ at 0.5 and $10 \mathrm{~m}$ depth during the period 7 to 12 June 1982 in Lindasspollene. $n=33, r^{2}=$ coefficient of determination, $p=$ significance level

\begin{tabular}{|lcccrccc|}
\hline \multicolumn{2}{c}{$\begin{array}{c}\text { Variables } \\
\mathrm{y}\end{array}$} & $\mathrm{x}$ & $\begin{array}{c}\text { Depth } \\
(\mathrm{m})\end{array}$ & \multicolumn{4}{c}{ Regression $(\mathrm{Y}=\mathrm{vx}+\mathrm{u})$} \\
\hline $\mathrm{P}_{\max }^{\mathrm{B}}$ & $\alpha^{\mathrm{B}}$ & 0.5 & 370.8 & -1.49 & 0.77 & 0.01 \\
& & 10 & 147.3 & 0.54 & 0.79 & 0.01 \\
$\mathrm{P}_{\text {max }}^{\mathrm{B}}$ & $\mathrm{I}_{\mathrm{K}}$ & 0.5 & 0.0144 & -0.84 & 0.71 & 0.01 \\
& & 10 & -0.0021 & 2.49 & 0.01 & - \\
$\alpha^{\mathrm{B}}$ & $\mathrm{I}_{\mathrm{K}}$ & 0.5 & $2.3 \times 10^{-5}$ & 0.01 & 0.25 & 0.01 \\
& & 10 & $-6.0 \times 10^{-5}$ & 0.02 & 0.28 & 0.01 \\
& & & & & & & \\
\hline
\end{tabular}

Marra \& Heinemann 1982, Prézelin et al. 1986, Rivkin \& Putt 1988). Malone (1971) and Paerl \& Mackenzie (1977) emphasized a difference between nano$(<22 \mu \mathrm{m})$ and netplankton $(>22 \mu \mathrm{m})$ in this context. They found that nan- and netplankton had their maximal photosynthetic activities in the morning and afternoon, respectively. Our findings do not contradict this generalization since nanoplankton were predominant in the upper $10 \mathrm{~m}$ of the water column in Lindåspollene. For a spring bloom of the colony forming haptophycean Phaeocystis pouchetii in Balsfjorden and Skjomen, northern Norway, the highest photosynthetic rates occurred in the afternoon (Eilertsen \& Taasen 1981). In their study the maximum photosynthetic rate was about 2 times the minimum value, as opposed to 4 to 5 times in our study.

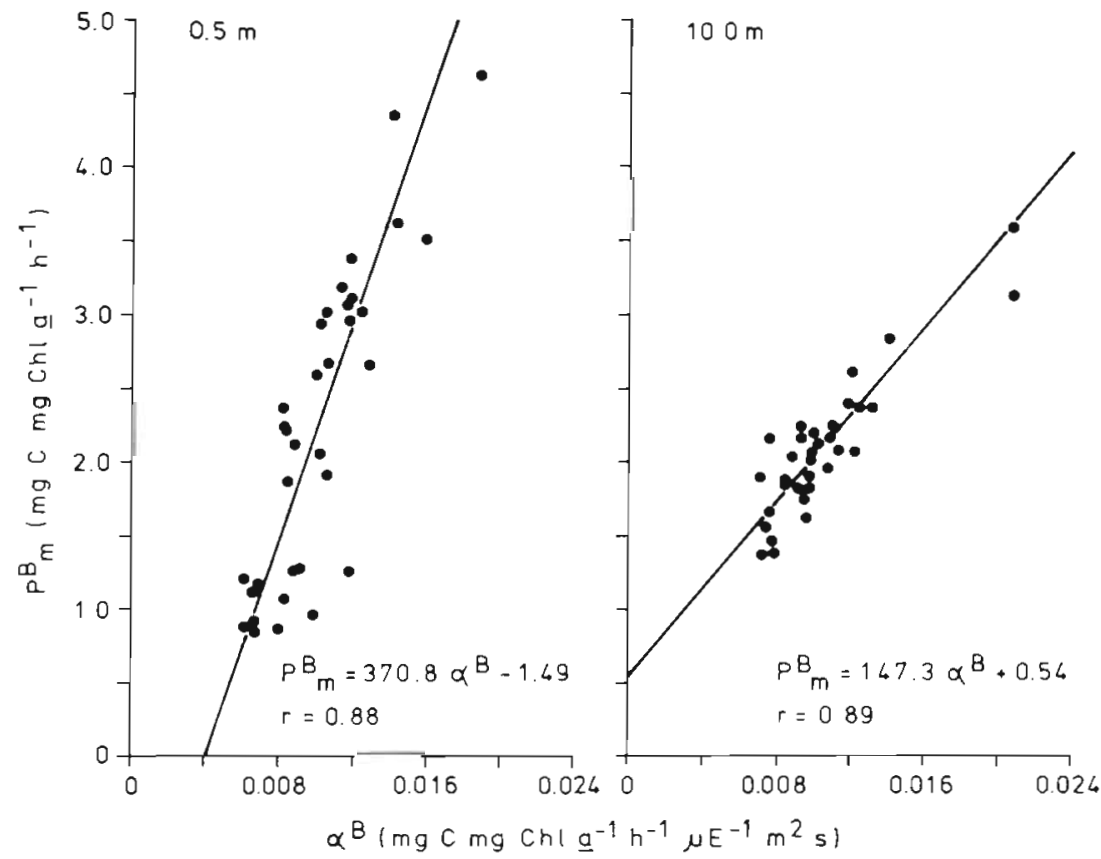

Fig. 8. Relationships between $\alpha^{\mathrm{B}}$ and $\mathrm{P}^{\mathrm{B}}{ }_{\max }$ $\left(\mathrm{P}^{\mathrm{B}} \mathrm{m}\right)$ at 0.5 and $10 \mathrm{~m}$ in Lindasspollene for the period 7 to 12 June 1982. The functional regression lines are calculated according to Ricker (1973); $\mathrm{n}=33$; r: correlation coefficient 


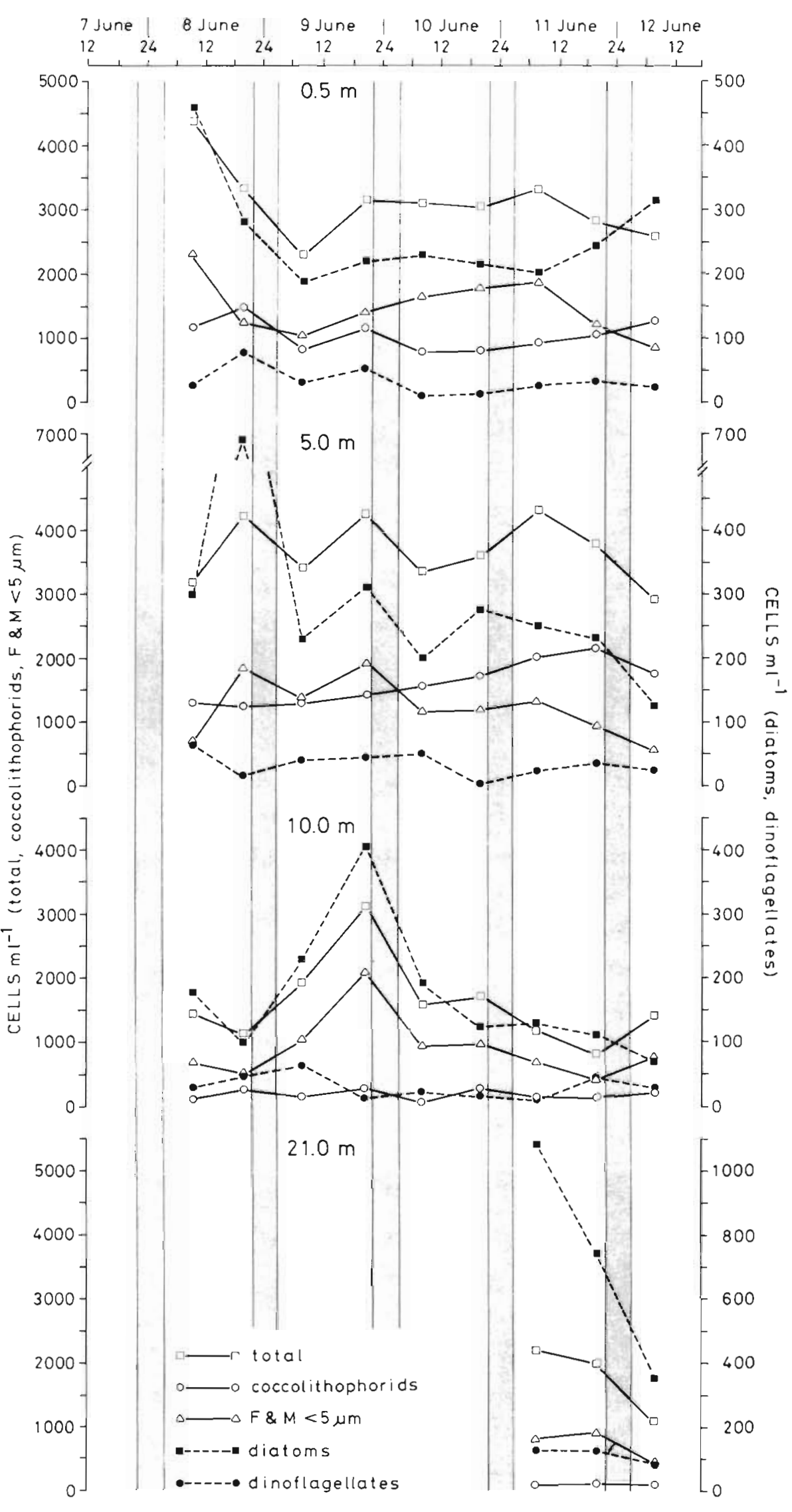

Fig. 9. Diel variations in phytoplankton cell numbers at $0.5,5$, and $10 \mathrm{~m}$ during the period 7 to 12 June 1982 in Lindåspollene and at $21 \mathrm{~m}$ from 11 to 12 June. The scale for the total fraction, coccolithophorids and flagellates \& monads $<5 \mu \mathrm{m}$ is to the left, while the scale for diatoms and dinoflagellates is to the right. Note the difference in scale. Shaded columns show periods of darkness 
The IVF/chl a ratio tended to increase during the day from low values early in the morning to high values in the afternoon or night (Fig. 4). A tendency towards low values of this ratio at high light intensities and high values at low light intensities has been found in previous studies (Kiefer 1973a, Karabashev \& Solovyev 1977. Prézelin \& Sweeney 1977, Setser et al. 1982, Fuhrman et al. 1985, Pingree \& Harris 1988). This suggests that chlorophyll a fluorescence is highly influenced by light (Vincent 1979). Other factors that may play a role are the physiological state of the cells, the species composition and the cell size (Kiefer 1973b. Setser et al. 1982, Alpine \& Cloern 1985, Falkowski \& Kiefer 1985).

In Lindasspollene the diel variations in photosynthetic capacity and chlorophyll a fluorescence seemed to be opposite (Figs. 4 and 6). This may indicate that the underlying mechanism of the diel rhythm in photosynthesis is closely connected with energy transfer processes in the thylakoid membrane (Prézelin \& Sweeney 1977). According to Vincent (1979) high light intensities could lead to a transfer of excitation energy from the highly fluorescent photosystem II to the weakly fluorescent photosystem I, thereby reducing the chlorophyll a fluorescence dramatically. From this one may hypothesize that such a mechanism could save energy for the dark reactions of photosynthesis. Samuelsson et al. (1983) found that the diel rhythm in photosynthesis of the dinoflagellate Gonyaulax polyedra was mainly regulated by photosystem II.

Mean values of chlorophyll a were $40 \%$ higher at $10 \mathrm{~m}$ than at $0.5 \mathrm{~m}$, while light utilization efficiency $\left(\alpha^{8}\right)$ did not change with depth (Table 1). Investigations on the vertical distribution of phytoplankton revealed that cell carbon and species composition remained unchanged down to $10 \mathrm{~m}$ (Skjoldal \& Erga unpubl.). Such a response could therefore be indicative of shade adaptation of the algal cells.

Platt \& Jassby (1976) suggested that $\alpha^{B}$ and $\mathrm{P}_{\text {max }}^{\mathrm{B}}$ are uncoupled physiologically. Thus, the initial slope of the P vs I curve $\left(\alpha^{B}\right)$ is mainly a function of the photochemical processes of photosynthesis (Côté \& Platt 1983), depending upon the pigment content of the cell and on the absorption characteristics of these pigments (Harris 1980). Photosynthetic capacity expressed per unit chlorophyll $\left(\mathrm{P}^{\mathrm{B}}{ }_{\max }\right)$ is also sensitive to light variations, but in addition, is a function of the enzymatic processes in the dark reactions of photosynthesis. Therefore, it is also dependent upon other environmental factors such as nutrients and temperature (Harris 1980, Côté \& Platt 1983). Nitrate and orthophosphate concentrations in the uppermost $10 \mathrm{~m}$ in Lindaspollene were not above $0.1 \mu \mathrm{M}$ (Skjoldal \& Erga unpubl.). A moderate nutrient stress may thus be assumed for the phytoplankton of these strata. According to this, the observed morning peak in photosynthetic activity could be a response to accumulation of nutrients in the cell during the night. This increased nutrient pool may enable the phytoplankton cells to metabolize the endproducts of the dark reactions of photosynthesis, thereby speeding up the photochemical processes. In accordance with this, Raimbault \& Mingazzini (1987) found a strong diurnal pattern in nitrate storage for $\mathrm{N}$-limited marine diatoms, with maximum accumulation occurring in the morning.

The photosynthetic parameters $\alpha^{\mathrm{B}}$ and $\mathrm{P}^{\mathrm{B}}$ max were linearly correlated at both 0.5 and $10 \mathrm{~m}$ in Lindåspollene (Fig. 8, Table 2). This indicates a phased diel periodicity in $\alpha^{\mathrm{B}}$ and $\mathrm{P}_{\text {max }}^{\mathrm{B}}$. Similar relationships have been described for natural phytoplankton off California, USA (Harding et al. 1982a), in Bedford Basin, Canada (Côté \& Platt 1983), in Chesapeake Bay, USA (Harding et al. 1985, Harding \& Jones 1988), on the Pacific coast of Canada (Forbes et al. 1986), in the Gulf of Maine, USA (Legendre et al. 1988) and in McMurdo Sound, Antarctica (Rivkin \& Putt 1988), MacCaull \& Platt (1977) and Putt \& Prézelin (1985) found no diel rhythm in $\alpha^{\mathrm{B}}$, but only in $\mathrm{P}_{\text {max }}^{\mathrm{B}}$, for natural phytoplankton during summer in Bedford Basin (Canada) and in Santa Barbara Channel (USA), respectively.

The difference between 0.5 and $10 \mathrm{~m}$ in our study reflected a basic difference between the diel cycles of $\mathrm{P}^{\mathrm{B}}{ }_{\max }$ and $\alpha^{\mathrm{B}}$ at the 2 depths. $\alpha^{\mathrm{B}}$ showed similar cycles with almost identical means and standard deviations at 0.5 and $10 \mathrm{~m}$ (Table 1, Fig. 6). $\mathrm{P}_{\text {max }}^{\mathrm{B}}$ in contrast, showed much more pronounced variation at 0.5 than at $10 \mathrm{~m}$ (Table 1, Fig. 6). Probably this has to do with light adaptation (i.e. increased activity of the enzymatic processes in the dark reactions of photosynthesis). This was reflected in a much steeper linear relationship between $\mathrm{P}_{\text {max }}^{\mathrm{B}}$ and $\alpha^{\mathrm{B}}$ at 0.5 than at $10 \mathrm{~m}$ (Fig. 8). Such a pattern has also been described by Harding et al. (1987). $\mathrm{I}_{K}$ is derived as the ratio between $\mathrm{P}^{B}{ }_{\max }$ and $\alpha^{\mathrm{B}}$. Due to the relatively greater diel variation in $\mathrm{P}_{\text {max }}^{\mathrm{B}}$ than in $\alpha^{\mathrm{B}}$ at $0.5 \mathrm{~m}, \mathrm{I}_{\mathrm{K}}$ changed by a factor of 2 to 3 (Fig. 6 ). Therefore the slope of the regression (linear) describing the relationship between $\mathrm{P}^{\mathrm{B}}$ max and $\alpha^{\mathrm{B}}$ (Fig. 8) cannot be defined as an overall mean value of $I_{K}$ at $0.5 \mathrm{~m}$. This disparity was less pronounced at $10 \mathrm{~m}$ due to a more similar pattern of variation in $\alpha^{\mathrm{B}}$ and $\mathrm{P}^{\mathrm{B}}$ max. $\mathrm{I}_{K}$ was only weakly correlated with $\alpha^{\mathrm{B}}$ at both depths (Table 2). An uncorrelated relationship between $\mathrm{I}_{K}$ and $\alpha^{B}$ has been taken to infer that the photochemical and dark processes of photosynthesis are uncoupled physiologically (Platt \& Jassby 1976). This interpretation may not be that straightforward, however, since $I_{K}$ is derived from both $\alpha^{B}$ and $P^{B}$ max. Thus, the highly phased and correlated relationship between $\alpha^{B}$ and $P^{B}$ max suggests the opposite, i.e. closely coupled processes.

For cultures of marine phytoplankton a phased periodicity in $\alpha^{B}$ and ${P^{B}}_{\text {max }}$ has been widely 
documented (Prézelin \& Sweeney 1977, Prézelin \& Matlick 1980, Harding et al. 1981a, b, 1983, 1987, Putt \& Prézelin 1988). In Lindåspollene the diel rhythm in photosynthesis (Figs, 6 and 7) was not accompanied by a similar periodicity in chlorophyll a concentrations (Fig. 4). This is also consistent with the findings of Prézelin et al. (1977), Prézelin \& Matlick (1980), Harding et al. (1981a, 1982a) and Legendre et al. (1988). The independence of chlorophyll a concentrations and P-I periodicity has been interpreted as reflecting an endogenous rhythm regulating diel oscillations in photosynthesis (Harding et al. 1982a, Legendre et al. 1988). Other authors also lend support to the hypothesis that the circadian rhythm of photosynthesis is controlled by an endogenous component (Sournia 1974, Prézelin \& Sweeney 1977, Prézelin et al. 1977. Harding et al. 1981a, Côté \& Platt 1983). Such an endogenous mechanism is believed to be entrained by environmental factors (Enright 1970, Stross et al. 1973). Among these, nutrient deficiency and nutrient availability, and light:dark cycles were probably the most important in Lindåspollene.

Acknowledgements. We thank Dr Svein Kristiansen for valuable co-operation during the field work and Elin Holm for drawing the figures. Prof. Egil Sakshaug gave valuable comments on an earlier draft of the manuscript. Thanks are also due to Dr Lawrence W. Harding, Jr and 2 anonymous reviewers for critically reviewing the manuscript. This study was supported by the Norwegian Marine Pollution Research and Monitoring Programme.

\section{LITERATURE CITED}

Aksnes, D. L., Magnesen, T (1983). Distribution, development, and production of Calanus finmarchicus (Gunnerus) in Lindåspollene, western Norway, 1979. Sarsia 68: 195-208

Aksnes, D. L., Magnesen, T. (1988). A population dynamics approach to the estimation of production of four calanoid copepods in Lindåspollene, western Norway. Mar. Ecol. Prog. Ser. 45: 57-68

Aksnes, D. L., Magnesen, T., Lie, U. (1985). Nutrient enrichment experiments in plastic cylinders and the implications of enhanced primary production in Lindåspollene, western Norway. Sarsia 70: 45-58

Alpine, A. E., Cloern, J. E. (1985). Differences in in vivo fluorescence yield between three phytoplankton size classes. J. Plankton Res. 7: 381-390

Aure, J. N. (1972). Hydrografien i Lindåspollene. Cand. real thesis, Univ. of Bergen

Berge, G. (1962). Discoloration of the sea due to Coccolithus huxleyi 'bloom'. Sarsia 6: 27-40

Brand, L. E. (1982). Persistent diel rhythms in the chlorophyl fluorescence of marine phytoplankton species. Mar Biol. 69: 253-262

Cosper, E. (1982). Influence of light intensity on diel variations in rates of growth, respiration and organic release of a marine diatom: comparison of diurnally constant and fluctuating light. J. Plankton Res. 4: 705-724
Côté, B., Platt, T. (1983). Day-to-day variations in the springsummer photosynthetic parameters of coastal marine phytoplankton. Limnol. Oceanogr 28: 320-344

Dahl, O., Ostvedt, O. J., Lie, U. (1973). An introduction to a study of the marine ecosystem and the local herring stock in Lindåspollene. FiskDir Skr (Ser HavUnders.) 16: $148-158$

Doty, M. S. Oguri, M. (1957). Evidence for a photosynthetic daily periodicity. Limnol. Oceanogr. 2: $37-40$

Dring, M. J., Jewson, D. H. (1982). What does the ${ }^{14} \mathrm{C}$ uptake by phytoplankton really measure? A theoretical modelling approach. Proc. R. Soc. B 214: 351-368

Eilertsen, H. Chr, Taasen, J. P. (1981). Diel variations in some important phytoplankton parameters during a 24 hours sampling period in Balsfjorden. Tromso and Skjomenfjorden, Nordland, North Norway. Kieler Meeresforsch. Sonderh. 5: 68-81

Enright, J. T. (1970). Ecological aspects of endogenous rhythmicity. A. Rev. Ecol. Syst. 1: 221-238

Eppley, R. W., Coatsworth, J. L. (1966). Culture of the marine phytoplankter Dunaliella tertiolecta, with light-dark cycles. Arch. Microbiol. 55: 66-80

Eppley, R. W., Rogers, J. N., McCarthy, J. J. (1969). Halfsaturation constants for uptake of nitrate and ammonium by marine phytoplankton. Limnol. Oceanogr. 14: 912-920

Erga, S. R. (1989a). Ecological studies on the phytoplankton of Boknafjorden, western Norway. I. The effect of water exchange processes and environmental factors on temporal and vertical variability of biomass. Sarsia 74 $161-176$

Erga, S. R. (1989b). Ecological studies on the phytoplankton of Boknafjorden, western Norway. II. Environmental control of photosynthesis. J. Plankton Res. 11: 785-812

Erga, S. R., Heimdal, B. R. (1984). Ecological studies on the phytoplankton of Korsfjorden, western Norway. The dynamics of a spring bloom seen in relation to hydrographical conditions and light regime. J. Plankton Res. 6: $67-90$

Falkowski, P. G. (1980). Light-shade adaptation in marine phytoplankton. In: Falkowski, P. G. (ed.) Primary productivity in the sea. Plenum Press, New York, p. 99-119

Falkowski, P. G., Kiefer, D. A. (1985). Chlorophyll a fluorescence in phytoplankton: relationship to photosynthesis and biomass. J. Plankton Res. 7: 715-731

Forbes, J. R., Denman, K. L., Mackas, D. L. (1986). Determinations of photosynthetic capacity in coastal marine phytoplankton: effects of assay irradiance and variability of photosynthetic parameters. Mar. Ecol. Prog. Ser. 32: 181-191

Fuhrman, J. A., Eppley, R. W., Hagstrom, A., Azam, F. (1985) Diel variations in bacterioplankton, phytoplankton, and related parameters in the Southern California Bight. Mar. Ecol. Prog. Ser 27: 9-20

Gargas, E., Hare, I., Martens, P., Edler, L. (1979). Diel changes in phytoplankton photosynthetic efficiency in brackish waters. Mar. Biol. 52: 113-122

Glover, H. E., Smith, A. E. (1988). Diel changes of carbon incorporation into biochemical constituents of Synechococcus spp. and larger algae in the Northwest Atlantic Ocean. Mar. Biol. 97: 259-267

Harding, L. W., Jr, Heinbokel, J. F. (1984). Periodicities of photosynthesis and cell division: behavior of phase-lagged replicate cultures of Ditylum brightwellii in a diurnally varying photic regime. Mar. Ecol. Prog. Ser. 15: 225-232

Harding, L. W., J厂, Jones, T. W. (1988). Carbon metabolism in estuarine phytoplankton: regulation of photosynthetic fixation patterns. Biol. Oceanogr. 5: 183-214 
Harding, L. W., Jr, Meeson, B. W., Fisher, T. R., Jז (1985). Photosynthesis patterns in Chesapeake Bay phytoplankton: short- and long-term responses of P-I curve parameters to light. Mar. Ecol. Prog. Ser. 26: 99-111

Harding, L. W., Jr, Meeson, B. W., Prézelin, B. B., Sweeney, B. M. (1981a). Diel periodicity of photosynthesis in marine phytoplankton. Mar. Biol. 61. 95-105

Harding, L. W., Jr, Meeson, B. W., Tyler, M. A. (1983). Photoadaptation and diel periodicity of photosynthesis in the dinoflagellate Prorocentrum mariae-lebouriae. Mar. Ecol. Prog. Ser. 13: 73-85

Harding, L. W., Jr, Prézelin, B. B., Sweeney, B. M, Cox, J. L. (1981b). Diel oscillations in the photosynthesis-irradiance relationship of a planktonic marine diatom. J Phycol. 17: 389-394

Harding, L. W., Jr, Prézelin, B. B., Sweeney, B. M., Cox, J. L. (1982a). Diel oscillations of the photosynthesis-irradiance (P-I) relationship in natural assemblages of phytoplankton. Mar. Biol. 67: 167-178

Harding, L. W., Jr, Prézelin, B. B., Sweeney, B. M., Cox, J. L. (1982b). Primary production as influenced by diel periodicity of phytoplankton photosynthesis. Mar. Biol. 67: 179-186

Harding, L. W., Jr, Tyler, M. A., Fisher, T. R., Jr (1987). Adaptive responses of photosynthesis in phytoplankton: specificity to time scale of change in light. Biol. Oceanogr. 4: $403-437$

Harris, G. H. (1980). The measurement of photosynthesis in natural populations of phytoplankton. In: Morris, I. (ed.). The physiological ecology of phytoplankton. Studies in Ecology, Vol. 7. Blackwell Scientific Publications, Oxford, p. $129-187$

Hitchcock, G. L. (1980). Diel variations in chlorophyl a, carbohydrate and protein content of the marine diatom Skeletonema costatum. Mar. Biol. 57: 271-278

Holm-Hansen, O., Riemann, B. (1978). Chlorophyll a determination: improvements in methodology. Oikos 30:438-447

Karabashev, G. S., Solovyev, A. N. (1977). Spatial and temporal variability of pigment fluorescence in living phytoplankton cells. Polskie Arch. Hydrobiol. 24 suppl.: 201-213

Kiefer, D. A. (1973a). Fluorescence properties of natural phytoplankton populations. Mar. Biol. 22: 263-269

Kiefer, D. A. (1973b). Chlorophyll a fluorescence in marine centric diatoms: responses of chloroplasts to light and nutrient stress. Mar. Biol. 23: 39-46

Lännergren, C. (1976). Primary production in Lindåspollene, a Norwegian land locked fjord. Botanica mar 19: 259-272

Lännergren, C. (1979). Buoyancy of natural populations of maarine phytoplankton. Mar. Biol. 54: 1-10

Lännergren, C., Skjoldal, H. R. (1976). The spring phytoplankton bloom in Lindåspollene, a land-locked Norwegian fjord. Autotrophic and heterotrophic activities in relation to nutrients. In: Persoone, G., Jaspers, E. (eds.) Proc. Tenth Eur. Mar. Biol. Symp., Vol. 2. Universa Press, Wettern, p. 363-391

Legendre, L., Demers, S., Garside, C., Haugen, E. M., Phinney, D. A., Shapiro, L. P., Therriault, J.-C., Yentsch, C. M. (1988). Circadian photosynthetic activity of natural marine phytoplankton isolated in a tank. J. Plankton Res. 10: 1-6

Lie, U., Magnesen, T., Tunberg, B., Aksnes, D. (1983). Preliminary studies on the vertical distribution of size-fractions in the zooplankton community in Lindaspollene, western Norway. Sarsia 68: 65-80

Litaker, W., Duke, C. S., Kenney, B. E., Ramus, T J. (1988). Diel chl $a$ and phaeopigment cycles in a shallow tidal estuary: potential role of microzooplankton grazing. Mar. Ecol. Prog. Ser. 47: 259-270
Lorenzen, C. J. (1963). Diurnal variation in photosynthetic activity of natural phytoplankton populations. Limnol. Oceanogr. 8: 56-62

MacCaull, W. A., Platt, T. (1977). Diel variations in the photosynthetic parameters of coastal marine phytoplankton. Limnol. Oceanogr. 22: 723-731

Magnesen, T., Aksnes, D., Skjoldal, H. R. (1989). Fine-scale vertical structure of a summer zooplankton community in Lindåspollene, western Norway. Sarsia 74: 115-126

Malone, T. C. (1971). The relative importance of nannoplankton and netplankton as primary producers in the California Current system. Fish. Bull. U.S. 69: 799-820

Marra, J. (1978). Phytoplankton photosynthetic response to vertical movement in a mixed layer. Mar. Biol. 46: 203-208

Marra, J. (1980). Time course of light intensity adaptation in a marine diatom. Mar. Biol. Lett. 1: 175-183

Marra, J., Heinemann, K. (1982). Photosynthesis response by phytoplankton to sunlight variability. Limnol. Oceanogr. 27: 1141-1153

Matthews, J. B. L., Heimdal, B. R. (1980). Pelagic productivity and food chains in fjord systems. In: Freeland, H. J. Farmer, D. M., Levings, C. D. (eds.) Fjord oceanography. Plenum Press, New York, p. 377-398

McAllister, C. D. (1963). Measurements of diurnal variation in productivity at ocean station ' $\mathrm{P}$ ' Limnol. Oceanogr. 8 289-292

Nelson, D. M., Brand, L. E. (1979). Cell division periodicity in 13 species of marine phytoplankton on a light: dark cycle. J. Phycol. 15: 67-75

Okada, H., Honjo, S. (1973). The distribution of oceanic coccolithophorids in the Pacific. Deep Sea Res. 20: 355-374

Owens, I. G., Falkowski, P. G., Whitledge, T. E. (1980). Diel periodicity in cellular chlorophyll content in marine diatoms. Mar. Biol. 59: 71-77

Paasche, E. (1967). Marine plankton algae grown with light dark cycles. 1. Coccolithus huxleyi. Physiol. Plant. 20: 946-956

Paerl, H. W., Mackenzie, L. A. (1977). A comparative study of the diurnal carbon fixation patterns of nannoplankton and netplankton. Limnol. Oceanogr. 22: 732-738

Pingree, R. D., Harris, R. P. (1988). An in vivo fluorescence response in the Bay of Biscay in June. J. mar. biol. Ass. U.K. 68: 519-529

Platt, T., Gallegos, C. L., Harrison, W. G. (1980). Photoinhibition of photosynthesis in natural assemblages of marine phytoplankton. J. Mar. Res. 38: 687-701

Platt, T., Jassby, A. D. (1976). The relationship between photosynthesis and light for natural assemblages of coastal marine phytoplankton. J. Phycol. 12: 421-430

Prézelin, B. B. (1981). Light reactions in photosynthesis. In: Platt, $\mathrm{T}$ (ed.) Physiological bases of phytoplankton ecology. Can. Bull. Fish. Aquat. Sci. 210: 1-43

Prézelin, B. B., Glover, H. E., Campbell, L. (1987). Effects of light intensity and nutrient availability on diel patterns of cell metabolism and growth in populations of Synechococcus spp. Mar. Biol. 95: 469-480

Prézelin, B. B., Ley, A. C. (1980). Photosynthesis and chlorophyll a fluorescence rhythms of marine phytoplankton. Mar. Biol. 55: 295-307

Prézelin, B. B., Matlick, H. A. (1980). Time-course of photoadaptation in the photosynthesis-irradiance relationship of a dinoflagellate exhibiting photosynthetic periodicity. Mar Biol. 58: 85-96

Prézelin, B. B., Meeson, B. W. Sweeney, B. M. (1977). Characterization of photosynthetic rhythms in marine dinoflagellates. I. Pigmentation, photosynthetic capacity and respiration. Plant. Physiol. 60: 384-387 
Prézelin, B. B., Putt, M., Glover, H. E. (1986). Diurnal patterns in photosynthetic capacity and depth-dependent photosynthesis-irradiance relationships in Synechococcus spp. and larger phytoplankton in three water masses in the Northwest Atlantic Ocean. Mar. Biol. 91: 205-217

Prézelin, B. B., Sweeney, B. M. (1977). Characterization of photosynthetic rhythms in marine dinoflagellates. II. Photosynthesis-irradiance curves and in vivo chlorophyll a fluorescence. Plant. Physiol. 60: 388-392

Putt, M., Prézelin, B. B. (1985). Observations of diel patterns of photosynthesis in cyanobacteria and nanoplankton in the Santa Barbara Channel during 'el Nino' J. Plankton Res. 7: 779-790

Putt, M., Prézelin, B. B. (1988). Diel periodicity of photosynthesis and cell division compared in Thalassiosira weissflogii (Bacillariophyceae). J. Phycol. 24: 315-324

Putt, M., Rivkin, R. B., Prézelin, B. B. (1988). Effects of altered photic regimes on diel patterns of species-specific photosynthesis. I. Comparison of polar and temperate phytoplankton. Mar. Biol. 97: 435-443

Quéguiner, B., Legendre, L. (1986). Phytoplankton photosynthetic adaptation to high frequency light fluctuations simulating those induced by sea surface waves. Mar. Biol. 90: $483-491$

Raimbault, P., Mingazzini, M. (1987). Diurnal variations of intracellular nitrate storage by marine diatoms: effects of nutritional state. J. exp. mar. Biol. Ecol. 112: 217-232

Ricker, W. E. (1973). Linear regressions in fishery research. J. Fish. Res. Bd Can. 30: 409-434

Rivkin, R. B., Putt, M. (1988). Seasonal patterns of diel periodicity in photosynthesis by polar phytoplankton: species-specific responses. J. Phycol. 24: 369-376

Samuelsson, G., Sweeney, B. M., Matlick, H. A., Prézelin, B. B. (1983). Changes in photosystem II account for the circadian rhythm in photosynthesis in Gonyaulax polyedra. Plant. Physiol. 73: 329-331

Setser, P. J., Guinasso, N. L., Jr, Schink, D. R. (1982). Daily patterns of fluorescence in vivo in the central equatorial Pacific. J. mar. Res. 40: 453-471

This article was submitted to the editor
Skjoldal, H. R., Johannessen, P., Klinken, J., Haldorsen, H (1983). Controlled ecosystem experiment in Lindåspollene, western Norway, June 1979: comparisons between the natural and two enclosed water columns. Sarsia 68: 47-64

Skjoldal, H. R., Lännergren, C. (1978). The spring phytoplankton bloom in Lindasspollene, a land-locked Norwegian fjord. II. Biomass and activity of net and nanoplankton. Mar. Biol. 47: 313-323

Skjoldal, H. R., Wassmann, P. (1986). Sedimentation of particulate organic matter and silicium during spring and summer in Lindåspollene, western Norway, Mar. Ecol. Prog. Ser. 30: 49-63

Sournia, A. (1974). Circadian periodicities in natural populations of marine phytoplankton. Adv, mar. Biol. 12: 325-389

Steemann Nielsen, E. (1952). The use of radio-active carbon $\left({ }^{14} \mathrm{C}\right)$ for measuring organic production in the sea. J. Cons. perm. int. Explor. Mer 18: 117-140

Stross, R. G., Chisholm, S. W., Downing, T. A. (1973). Causes of daily rhythms in photosynthetic rates of phytoplankton Biol. Bull. mar. biol. Lab., Woods Hole 145: 200-209

Taguchi, S. (1976). Short-term variability of photosynthesis in natural marine phytoplankton populations. Mar. Biol. 37 : $197-207$

Utermöhl, H. (1931). Neue Wege in der quantitativen Erfassung des Planktons. (Mit besonderer Berücksichtigung des Ultraplanktons). Verh. int. Verein. theor. angew. Limnol 5: $567-596$

Vincent, W. F. (1979). Mechanisms of rapid photosynthetic adaptation in natural phytoplankton communities. I. Redistribution of excitation energy between photosystems I and II. J. Phycol. 15: 429-434

Vårum, K. M., Østgaard, K., Grimsrud, K. (1986). Diurnal rhythms in carbohydrate metabolism of the marine diatom Skeletonema costatum (Grev.) Cleve. J. exp. mar Biol. Ecol. 102: 249-256

Wassmann, P. (1983). Sedimentation of organic and inorganic particulate material in Lindåspollene, a stratified, landlocked fjord in western Norway. Mar. Ecol. Prog. Ser 13: $237-248$

Manuscript first received: August 7, 1989

Revised version accepted: May 7, 1990 